Yüzüncü Yil Üniversitesi
Tarim Bilimleri Dergisi

Araştırma Makalesi (Research Article)

Antifungal and Antibacterial Effect of Dodder (Cuscuta campestris) Used for Hepatitis Treatment of Mothers and Newborn Infants in Province Mardin in Turkey

\author{
Pınar ERECEVITT SÖNMEZ *1, Sevda KIRBAĞ ${ }^{2}$, Sule İNCİ ${ }^{2}$ \\ ${ }^{1}$ Department of Medical Services and Techniques, Pertek Sakine Genç Vocational School, Munzur University, \\ TR 62000-Tunceli, TURKEY ${ }^{2}$ \\ ${ }^{2}$ Department of Biology, Science Faculty, Firat University, TR 23119-Elazığg, TURKEY \\ *Corresponding author e-mail: pinarerecevit@hotmail.com, perecevit@munzur.edu.tr
}

Article Info

Received: 17.08.2019

Accepted: 11.12.2019

Online Published 31.12.2019

DOI: 10.29133 /yyutbd.605970

\section{Keywords}

Agar disc diffusion method,

Antimicrobial effect,

Dodder,

Pathogen microorganisms,

The broth microdilution.

\begin{abstract}
Dodder is a plant used for the hepatitis treatment in new born infants in and around Mardin. The aim of this research to determine the antifungal and antibacterial effects of traditionally used dooder is known as a regional folk remedy. Thus and so, the efficacy of the drug has been demonstrated by the inclusion of natural therapeutic antimicrobial agents such as anti-inflammatory and wound healing, including infectious diseases. The antimicrobial effects of these plant was analyzed against bacteria, yeast and dermatopyta fungi by the agar disc diffusion method. The nominal concentration of the plant to prevent from the development of microorganisms was detected with the broth microdulitions method. It was determined that it had sensitive and moderately sensitive antimicrobial effect against all of microrganisms (13-19.66 $\mathrm{mm} /$ inhibition zone), growth of tested microrganisms were inhibited at 50-6.25 $\mu \mathrm{L} . \mathrm{It}$ is though that this natural herbal resource can light the way for treatment of several diseases and direct the next studies because of having the potential for being used as a new antimicrobial agent.
\end{abstract}

\title{
Türkiye'de Mardin İlindeki Annelerin ve Yenidoğan Bebeklerin Sarılık Tedavisinde Kullanılan Küsküt'ün (Cuscuta campestris) Antifungal ve Antibakteriyel Etkileri
}

\section{Makale Bilgileri}

Geliș: 17.08.2019

Kabul: 11.12.2019

Online Yayınlanma 31.12.2019

DOI: $10.29133 /$ yyutbd.605970

\section{Anahtar kelimeler}

Agar disk diffizyon metod, Antimikrobiyal etki,

Küsküt,

Patojen mikrooranizmalar, Broth mikrodilüsyon.
Öz: Küsküt, Mardin ve çevresinde yeni doğan bebeklerde hepatit tedavisi için kullanılan bir bitkidir. Bu araştırmanın amacı yöresel bir halk ilacı olarak bilinen ve geleneksel olarak kullanılan küsküt'ün antifungal ve antibakteriyel etkisini tespit etmektir. Böylece, enfeksiyöz hastalıklar dahil anti-enflamatuar ve yara iyleştirici gibi doğal terapötik antimikrobiyal ajanların dahil edilmesi ile söz konusu ilacın etkinliği ortaya konmuştur. Bu bitkinin antimikrobiyal etkileri agar disk difüzyon yöntemi ile bakteri, maya ve dermatofit funguslara karşı analiz edilmiştir. Bitkinin mikroorganizma gelişimini engellemek için en düşük konsantrasyonu, broth mikrodilusyon metodu ile tespit edilmiştir. Küsküt bitkisinin; tüm mikroorganizmalara karşı güçlü ve orta düzeyde antimikrobiyal etkiye sahip olduğu (13-19.66 mm/inhibisyon zonu), test mikroorganizmalarının büyümesini $50-6.25 \mu \mathrm{L}$ de inhibe ettiği tespit edilmiştir. $\mathrm{Bu}$ doğal bitkisel kaynağın, yeni bir antimikrobiyal ajan olarak kullanılma potansiyeline sahip olması nedeniyle daha sonraki çalışmaları yönlendirmesi ve çeşitli hastalıkların tedavisine 1 şık tutacağı düşünülmektedir. 


\section{Introduction}

Medicinal plants in rural areas of developing countries, continued to be used as a primary source of medicine for human diseases (Palombo, 2009). While the various plant species are called by similar local names in different regions of Turkey, the same plant species are entitled by the different names. "KÜSKÜT (IKSUT)" or "Dodder" plant that has become like a part of the culture in and around Mardin is one of the quintessence.

This plant drug is used for liver diseases and hepatitis treatment of mothers and newborn infants; it also has identified by the culture and region mentioned. Much as the source of this drug that is benefited with intent to healing by herbalists and spice-sellers has become a research object for a long while, it is impossible to define the plant whose a powder dried part can be able to be obtained only. It was found at the end of the studies that this related fabulous plant is the Dodder (Cuscuta spp.) which is a parasite plant (Şekeroğlu and Koca, 2012).

According to Turkish Dictionary of Plant local names called in our country by dodder plant are as follows: Bostanbozan, Canavarotu, Bağbozan, Cinsaçı, Eftimon, Gelinsaçı, Kızıl sarmaşık, Küşküt and Şeytansaçı (Baytop, 1997).

It is proved by studies that due to its components, C. campestris (dodder) is effective on atopic dermatitis (Choopani et al., 2016); also effective on some of plant-pathogen fungus (Sin et al., 2011); has anticancer effect (Behbahani, 2014; Noureen et al., 2019); has analgesic, hypothermic, antiinflammatory, anti proliferative effect (Agha et al., 1996; Ghule et al., 2011; Lee et al., 2011); includes beneficial pharmacologically active markers such as kaempferol, bergenin and gallic acid (Singh and Shailajan, 2016). Moreover, C. pedicellata Ledeb has an antibacterial effect against isolates of Xanthomonas campestris that is isolated from unhealthy fruits (Amna et al., 2014); 24 different types of Cuscuta include different phytochemical components for the development of new herbal medicines (Ahmad et al., 2017).

However, it was determined that Cuscuta species had hepatoprotective and antioxidant activities (Koca-Caliskan et al., 2014a; Koca-Caliskan et al., 2014b; Koca-Caliskan et al., 2018).

It is also determined by studies that $C$. reflexa has an antibacterial and antifungal effect on Staphylococcus aureus, Staphylococcus epidermidis, Pseudomonas aeruginosa, Escherichia coli, Bacillus subtilis, Bacillus licheniformis and Aspergillus niger, Trichoderma ressei (Anjum and Khan, 2003; Summit et al., 2010). While extracts of C. racemosa including ethanol has partially effective on $S$. aureus, the same material has no antibacterial and antifungal impact on E. coli, $P$. aeruginosa, Candida albicans and A. niger (Ferraz et al., 2010). While extracts of $C$. australis are effective on $E$. coli, $S$. aureus, $P$. aeruginosa, the same extracts do not display an antimicrobial effect on $E$. coli, $S$. aureus, P. aeruginosa (Okiei et al., 2009).

Due to the development of resistant bacterial strains, there is an increase in the number of papers published on antimicrobial activity of plant extracts or different mixtures of plant extracts (synergistic effect) (Akyüz et al., 2012; Kırbağ et al., 2013; Erecevit and Kırbağ, 2017a; Erecevit and Kırbağ, 2017b; Küçükgül Güleç et al., 2014). Additionally cutaneous fungal infections induced by Trichophyton, Microsporum and Epidermophyton are among the most important unsolved global public health problems. Therefore, there is a need to discover new treatment alternatives (Badali et al., 2015).

In the previous studies, antifungal effects against dermatophyte fungi of Cuscuta campestris (dodder) have not been reported. For our knowledge, this is the first investigation on the evaluation of antibacterial and especially antifungal activities against Trichophyton sp., Epidermophyton sp. on methanolic extracts of this species. Moreover, due to its antimicrobial characteristics, is essential in terms of curing several diseases which threaten the human health including "tinea" disease (Kuta et al., 2008) related to Trichophyton sp. and Epidermophyton sp.

\section{Materials and Methods}

\subsection{Collection and extraction of plant material}

Dodder was collected from were collected during appropriate vegetation as the material from Mardin province in the Eastern Anatolia of Turkey. The taxonomic identification of plant material was 
determined by using the Flora of Turkey (Davis, 1970, 1984, 1985); it was performed by Prof Dr. Şemsettin Civelek who is a systematic-botanic specialist from Firat University. The collected plant was dried and triturated. The grinded plant $(5 \mathrm{~g})$ was treated in $20 \mathrm{~mL}$ methanol $(98.1 \%)$ solvent by keeping on a rotary shaker $(100 \mathrm{rpm})$ for $24 \mathrm{~h}$. Thus, the plant extract was obtained. The dodder extracts were filtered by using Whatman filter paper (No1) and stored at $4{ }^{0} \mathrm{C}$ for further study. Then, $100 \mu \mathrm{L}(25 \mathrm{mg} / \mathrm{L})$ extracts were injected into empty antibiotic paper discs having a diameter of $6 \mathrm{~mm}$ (Schleicher \&S hüll No: 2668, Germany) to separately try on each of the test microorganisms.

\subsection{Test microorganisms}

The microorganisms that were used for the present investigation; gram positive bacteria, gram negative bacteria, yeasts and dermatophyta fungi (Staphlococcus aureus COWAN 1, Bacillus megaterium DSM 32, Escherichia coli ATCC 25922, Pseudomonas aeruginosa DMS 50071 SCOTTA, Candida albicans FMC 17, Candida glabrata ATCC 66032, Trichophyton sp., Epidermophyton sp.). These microorganisms were provided by the Department of Biology, Faculty of Science, Firat University, Microbiology Laboratory, Elazig-Turkey.

\subsection{Preparation of microorganism cultures}

Bacterial strains will be cultivated in to Nutrient Buyyon medium and are incubated at $35 \pm 1^{\circ}$ $\mathrm{C}$ for 24 hours. The yeast strain sand dermatophyte fungi are respectivelly incubated on the Yeast Malt extract and Glucose Sabouroud medium at $25 \pm 1{ }^{\circ} \mathrm{C}$ for 48 hours. Cultures that grow in the broth medium will be transferred to the broth media tubes with pre-sterilized after setting in the Mc Farland (0.5) Standard tube.

\subsection{Sensitivity test}

The agar disc diffusion method were carried out to determine antimicrobial effect. Mueller Hinton Agar, Yeast Malt Extract Agar and Sabouraud Dextrose Agar sterilized seperately in the erlenmeyer flasks and cooled down to $45-50{ }^{\circ} \mathrm{C}$, with the culture of bacteria, yeast and fungus to be prepared as described above, will be vaccinated at the rate of $\% 1\left(10^{6}\right.$ cells / $\mathrm{mL}$ of bacteria, $10^{4}$ cells / $\mathrm{mL}$ yeast and cells / $\mathrm{mL}$ dermatophyta fungi as per Mc Farland standard).

After shaking well, $15 \mathrm{ml}$ medium is poured in to sterile petri plates and homogenously distributed. The discs (6 mm diameter) with treated 100 microliters of plant extract were added to the appropriate agar media inoculated with microorganism. Then, petri dishes was stored at $4{ }^{\circ} \mathrm{C}$ for $2 \mathrm{~h}$. The inoculated petri dishes were incubated at $37 \pm 0.1^{\circ} \mathrm{C}$ at $24 \mathrm{~h}$ for bacterial strains and also at $25 \pm 0.1$ ${ }^{0} \mathrm{C}$ at $72 \mathrm{~h}$ for yeasts and dermatophyta fungi. The antimicrobial sensitivity of plant extract was assesment by measuring the zone of inhibition against the microorganisms (Collins and Lyne, 1989). The positive control; mikostatin and ampicilin sulbactam was used. Methanol injected discs were tested as negative control.

\subsection{Detection of minimum inhibition concentration}

The minimum inhibitory concentrations (MIC) were determined with Broth dilution assay. The cultures were obtained in Mueller Hinton Broth (Difco, Difco Laboratories, Detroit, MI, USA). The inocula of microorganisms were obtained from $12 \mathrm{~h}$ broth cultures and suspensions were setting in $0.5 \mathrm{Mc}$ Farland Standard cloudiness. The plant sample was first rarefied to the maximum concentration $100 \mu \mathrm{L}$ to be tested, and then serial 2-fold subtilizations were acquired in a concentration serial from 6.25 to $100 \mu \mathrm{L}(1562-25000 \mu \mathrm{g})$ in $10 \mathrm{~mL}$ sterile test tubes including nutrient broth for bacteria and sabouraud dextrose broth for yeast and dermatophyta fungi. MIC values of this plant against analyzed microorganisms was revealed with a micro-well dilution method (Güllüce et al., 2004). Microorganisms reproduction was detected with optical density quantitiy at 600 $\mathrm{nm}$ using an EL x 800 universal microtiter plate reader. After incubation for $18-24 \mathrm{~h}$ at $37 \pm 1^{\circ} \mathrm{C}$ for bacteria, $25 \pm 0.1^{\circ} \mathrm{C}$ at $72 \mathrm{~h}$ for yeast and dermatophyta fungi. The MIC value was declared as the 
nominal concentration of the compounds to obstruction the reproduction of microorganisms or the final tube with no microbial reproduction was saved to symbolize $(\mathrm{mg} / \mathrm{mL})$.

\subsection{Statistical analysis}

Statistical comparisons among extract and cotrol groups (methanol, ampicillin sulbactam, mikostatin) were made with respect to the measurable antimicrobial activity against test microorganisms. SPSS 15.0 soft ware was used for statistic analysis (SPSS Inc., Chicago IL). The results were obtained with analysis of variance (ANOVA) and least significant difference (LSD) tests were given as mean \pm SE. $\mathrm{P}<0.0001, \mathrm{p}<0.001, \mathrm{p}>0.05$ were used for the differences between the extract and cotrol groups. $\mathrm{P}<0.0001$ and $\mathrm{p}<0.001$ were considered sensitive and moderately sensitive. This study was conducted in three repetition.

\section{Results}

Antibacterial and antifungal effects of the plant extract used in the study are given in Table 12. National Microbiology Standards and zone diameters comments in Infectious Diseases Laboratory Diagnosis Guide are as follows; if there is an inhibition area around the disc with a diameter of $\geq 14$ $\mathrm{mm}(15-30 \mathrm{~mm})$, the isolates examined are sensitive to Dodder. If there is an inhibition area around the disc with a diameter of $<14$; the isolates examined is moderately sensitive. If there is no zone, the isolates are accepted as resistant (Akbaş, 2014; Okut et al., 2018). In the previous studies, antifungal effects against dermatophyte fungi of $C$. campestris (dodder) have not been reported .

According to the inhibition effect of $C$. campestris extracts treatment with methanol on the development of test microorganisms, it was detected that they had significant sensitive and moderately sensitive antimicrobial effects against all of the microorganisms. By this way; E. coli, P. aeruginosa and C. albicans, C. glabrata (14.66 mm / inhibition zone), S. aureus (14.33 mm / inhibition zone), $B$. megaterium (17.66 mm / inhibition zone), Epidermophyton sp. (13.00 mm / inhibition zone), Trichophyton sp. (19.66 mm / inhibition zone).

Table 1. Antimicrobial effects of extracts of Cuscuta campestris (dodder) (mm)

\begin{tabular}{llll}
\hline Microorganisms & \multicolumn{2}{c}{ Inhibition zone $(\mathrm{mm})$} \\
& C. campestris & Control \\
& & Methanol & Standart antibiotics \\
\hline E. coli & $14.66 \pm 0.33^{\mathrm{d}}$ & - & $12.33 \pm 0.3^{*}$ \\
S. aureus & $14.33 \pm 0.33^{\mathrm{d}}$ & - & $10.33 \pm 0.3^{*}$ \\
B. megaterium & $17.66 \pm 0.33^{\mathrm{cd}}$ & - & $12.33 \pm 0.3^{*}$ \\
P. aeruginosa & $14.66 \pm 0.33^{\mathrm{d}}$ & - & $12.33 \pm 0.3^{*}$ \\
C. albicans & $14.66 \pm 0.33^{\mathrm{d}}$ & - & $12.66 \pm 0.6 *$ \\
C. glabrata & $14.66 \pm 0.33^{\mathrm{d}}$ & - & $9.33 \pm 0.66^{* *}$ \\
Epidermophyton sp. & $13.00 \pm 0.57^{\mathrm{d}}$ & - & $8.66 \pm 0.66^{* *}$ \\
Trichophyton sp. & $19.66 \pm 0.33^{\mathrm{cd}}$ & - & $8.66 \pm 0.66^{* *}$ \\
\hline
\end{tabular}

The positive control; ampicillin sulbactam $(*)$ and mikostatin $(* *)(120 \mu \mathrm{L}$ and $20 \mu \mathrm{g} /$ disc $)$, the negative control; methanol. Inhibition zone $\geq 14 \mathrm{~mm}$ (sensitive effect; $\mathrm{p}<0.0001 ; \mathrm{cd}$ ), $14<\mathrm{mm}$ moderately sensitive effect; $\mathrm{p}<0.001 ; \mathrm{d}$ ), not inhibited: (a: $\mathrm{p}>0.05)$

The standardized method of the NCCLS for determining susceptibility was used in a study indicating the effect of $C$. campestris on the proliferation of all of the gram-positive bacteria, the gram-negative bacteria, yeasts, and dermatophyte fungi. These microorganisms are among the most commonly found pathogens on the human. Our study showed that the effective dose for dermatophyte fungi was 50-6.25 $\mu \mathrm{L}$ (about $12500-6250 \mu \mathrm{g}$ ). 
With the microplate technique, the MIC value was 5 times lower at $15625 \mathrm{mg} / \mathrm{mL}$. In experiments up to this stage, $100 \mu \mathrm{L}$ of extract were used. Also, the efficiency of this method was compared with the standard disc diffusion method technique.

With the Broth dilution assay technique, the lowest inhibitory concentration of $C$. campestris extraction S. aureus, B. megaterium, P. aeruginosa, C. albicans, C. glabrata, Trichophyton sp. and E. coli, Epidermophyton sp. were determined as $6.25 \mu \mathrm{L}$ (about $1.562 \mathrm{mg} / \mathrm{mL}$ ) and $50 \mu \mathrm{L}$ (about $12.5 \mathrm{mg} /$ $\mathrm{mL}$ ) respectively. According to the disc diffusion method; the amount used for sensitivity is $25 \mathrm{mg} /$ $\mathrm{mL}$ on all of the microorganisms (Table No. 2).

When antibacterial, antifungal, antidermatophyta activity of $C$. campestris (iksut) extracts were analyzed to disc diffusion method (Table 1); it was detected that antimicrobial activity in the dodder extracts was present sensitive inhibition with compared to control group methanol and standard antibiotics (ampicillin for bacteria, mikostatin for yeast and dermatophyte fungi).

Table 2. The Minimum inhibition concentration (MIC in $100 \mu \mathrm{L}$ ) of C. campestris (dodder) extracts against the microorganisms

\begin{tabular}{ll}
\hline Test Microorganisms & MIC values $(\mu \mathrm{L})$ \\
\hline E. coli & C. campestris \\
S. aureus & 50.00 \\
B. megaterium & 6.25 \\
P. aeruginosa & 6.25 \\
C. albicans & 6.25 \\
C. glabrata & 6.25 \\
Epidermophyton sp. & 6.25 \\
Trichophyton sp. & 50.00 \\
\hline
\end{tabular}

\section{Discussion and Conclusion}

Concerning in vitro and in vivo studies performed, Cuscuta species have different pharmacological effects. There are many studies on the pharmacological and biological effects of Cuscuta chinensis (Nisa et al., 1986; Umehara et al., 2004). It is shown that C. chinensis glycosides have effects on aging and $C$. chinensis glycosides strengthen the memory by inducing PC12 cell differentiation (Liu et al., 2003). Subsequent studies revealed the antibacterial effects (Pal et al., 2006) of methanol extracts of $C$. reflexa bodies; antioxidant effects of ethyl acetate and methanol extract of C. chinensis (Yen et al., 2008). Moreover, antihypertensive (Oh et al., 2002) impacts of C. japonica's major components. Immunomodulator effect (Stanilova et al., 2000) of C. europea C3 binding glycoprotein; liver preventive effect (Yen et al., 2007) of ethanol extract of $C$. chinensis were confirmed. Finally, the methanol extract that is obtained from the $C$. reflexa body suppresses ovarian steroid ogeness in mice (Gupta et al., 20003). We identified that ethanol and aqueous extracts of hexane, chloroform, ethyl acetate, methanol and water extracts that are obtained from C. arvense have analgesic, anti-inflammatory effects (Koca et al., 2011).

There is no phytochemicals research on dodder species in Turkey as well as it is found studies that explain the phytochemicals content of plant extracts for different species of the same plant (Yen, et al., 2007) were found in analyses conducted on C. chinensis. Detailed studies revealed 1 trisaccharide, 4 new glycosidic acids, acetic acid, propionic acid, methyl butyric acid, tiglic acid, convolvulinic acid, and jalapinolic acid in a fraction that is similar to resin glycoside that is not dissolved in C. chinensis seeds (Du et al., 1998). Studies on C. japonica polar extracts showed that active components have caffeoylquinic acid derivatives and caffeoylvinylate derivatives (Oh et al., 2002).

In a study by Abdullah was found that Cuscuta europea $(25 \mathrm{mg} / \mathrm{ml})$ was not effective against E. coli, but it becomes impactful by $20.5 \mathrm{~mm}$ the inhibition zone against $S$. aureus (Abdullah et al., 2016). Another study was determined by Şen et al.; with reference to the results, none of the extracts showed antimicrobial sensitivity against bacteria (S. aureus, S. epidermidis, E. coli, K. pneumoniae, $P$. aeruginosa, Proteus mirabilis) and from yeasts; C. albicans, $C$. parapsilosis and C. tropicalis (Şen et 
al., 2018). On the other hand, it was determined that Cuscuta reflexa showed an inhibition zone from 6 to $17 \mathrm{~mm}$ against $S$. aureus, $P$. aeruginosa, Salmonella typhimurium, $P$. vulgaris and Shigella sonnei, K. pneumoniae (Mateen et al., 2011). For Okiei, extracts of Cuscuta australis is effective on E. coli, $S$. aureus, $P$. aeruginosa while they do not display antimicrobial effect on other bacteria and fungus (Okiei et al., 2009).

Shayanfar conducted a study and reported that $C$. campestris has an antibacterial effect against Salmonella typhi, Micrococcus loteus, S. aureus, S. epidermidis, P. aeruginosa, Streptococcus pyogens, Serratia marcescens, B. subtilis, E. coli and K. pneumoniae (Shayanfar, 2015). The results of our study show parallelism with other studies conducted. In the previous studies, antifungal effects against dermatophyte fungi of $C$. campestris (dodder) have not been reported.

Compared to our study, different results are due to both different species of the same genus and the amount of useful compounds they contain. Also, genotype, chemotype, geographic origin, environmental and soil conditions are all other parameters that affect the composition of the final natural product (Hacioğlu, 2005).

According to agar the disc diffusion methods; in this study was detected that methanol extracts of dodder had sensitive and moderately sensitive antimicrobial activity against all of the microorganisms. The MIC values of methanolic extracts were $S$. aureus, B. megaterium, $P$. aeruginosa, C. albicans, C. glabrata, Trichophyton sp. and E. coli, Epidermophyton sp. (respectively; $15625 \mathrm{mg} / \mathrm{mL}$ and $12500 \mathrm{mg} / \mathrm{mL}$ ).

It is thought that this natural herbal resource can light the way for the treatment of several diseases and direct the next studies because of having the potential for being used as a new antimicrobial agent. Thus, this study is light about pharmacological for the treatment of bacterial and fungal infections. The results of the study also showed that Dodder can treat cutaneous fungal infections caused by Epidermophyton sp. and Trichophyton sp.

\section{Acknowledgment}

The authors acknowledge that they have no conflict of interests

\section{References}

Abdullah, J. A, Hammadi, A. A., Hakem, R., Hatef, Z., \& Hussein, N. (2016). Study effect of plant extraction for Cuscuta europaea (Dodder) against two species of bacteria Staphylococcus aureus and Escherichia coli. Journal of Contemporary Medical Science, 2, 133- 137.

Agha, A. M., Sattar, E. A., \& Galal, A. (1996). Pharmacological Study of Cuscuta campestris Yuncker. Phytotherapy Research, 10, 1099-1573.

Ahmad, A., Tandon, S., Xuan, T. D., Nooreen, Z. (2017). A Review on Phytoconstituents and Biological activities of Cuscuta Species. Biomedicine \& Pharmacotherapy. 92, 772-795.

Akbaş, E. (2014). National Microbiology Standards and zone diameters comments in Infectious Diseases Laboratory Diagnosis Guide, Syndromic Diagnostic Approach, Sample Management, Test Procedures and Microbiological Diagnosis / Identification (Ulusal Mikrobiyoloji Standartları, Bulaşıcı Hastalıklar Laboratuvar Tanı Rehberi, Sendromik Tanı Yaklaşımı, Örnek Yönetimi, Test Prosedürleri ve Mikrobiyolojik Tanı/Tanımlama). Cilt: II, T.C. Sağlık Bakanlı̆̆l, Türkiye Halk Sağlı̆̆ Kurumu Başkanlığı, Mikrobiyoloji Referans Laboratuvarları Daire Başkanlığl, Ankara, s.222.

Akyüz, M., Onganer A. N., Erecevit P., \& Kirbağ S. (2012). Flavonoid Contents and 2,2-Diphenyl-1picrylhydrazyl Radical Scavenging Activity of some Edible Mushrooms from Turkey: $A$. bisporus and Pleurotus spp. Current Topics and Nutraceutical Research, 10, 133-136.

Ali, A., Haider, M. S., Hanif, S., \& Akhtar, N. (2014). African Journal of Biotechnology Assessment of the antibacterial activity of Cuscuta pedicellata Ledeb. African J. of Biotech., 13, 430-433.

Anjum, N., Khan, Z. (2003). Antimicrobial activity of the crude extract of Cuscuta reflexa Roxb. Pakistan Journal of Botany, 5, 999-1007.

Badali, H., Mohammadi, R., Mashedi, O., Sybren de Hoog, G., \& Meis, J. F. (2015). In vitro susceptibility patterns of clinically important Trichophyton and Epidermophyton species against nine antifungal drugs. Mycoses, 58, 303-307. 
Baytop, T. (1997). Turkish Plant Names Dictionary (Türkçe Bitki Adları Sözlüğü). Turkish Language Institution Publications (Türk Dil Kurumu Yayınları); Ankara, p.578.

Behbahani, M. (2014). Evaluation of In Vitro Anticancer Activity of Ocimum Basilicum, Alhagi Maurorum, Calendula officinalis and Their Parasite Cuscuta campestris. PLos One, 9, e116049.

Choopani, R., Mehrbani, M., Fekri, A., \& Mehrabani, M., (2016). Treatment of atopic dermatitis from the perspective of traditional persian medicine: presentation of a novel therapeutic approach. Journal of Evidence-Based Complementary \& Alternative Medicine, 22, 5-11.

Collins, C. H., Lyne, P. M. (1989). Microbiological Methods Butter worths \& Co. (Publishers) Ltd. pp. 410, London.

Davis, P. H. (1970-1984-1985). Flora of Turkey and the Aegean Islands. V: 7, 8, 9 Edinburgh Univ. Press. England.

Du, X. M., Kohinata, K, Kawasaki, T., Guo, Y. T., Miyahara. K. (1998). Components of the etherinsoluble resin glycoside-like fraction from Cuscuta chinensis. Phytochemistry, 48, 843-50.

Erecevit, P., \& Kırbağ, S. (2017). Antimicrobial activity of some plant species used for the medical purpose in Turkey. The Journal of Phytopharmacology, 6, 93-97.

Erecevit, P., \& Kırbağ, S. (2017). Determination of some biological properties over Kluyveromyces lactis 1 of Rheum ribes L. (Rhubarb) as a traditional medicinal and food plant. International Journal of Natural Life Science, 1, 22-31.

Ferraz, H. O., Silva, M. G., Carvalho, R., Suffredini, B., Kato, E. T. M., Arakaki, F., \& Bacchi, E. M. (2010). Phytochemical study and evaluation of the antimicrobial activity and cytotoxicity of Cuscuta racemosa. Revista Brasileira de Farmacognosia, 21.

Ghule R. S., Venkatnarayanan, R., Thakare, S. P., Jain, H., \& Ghule, P. R. (2011). Analgesic activity of Cuscuta campestris Yuncker a parasitic plant grown on Nerium indicum Mill. Journal of Advanced Pharmacy Education \& Research. 1, 45-51.

Gupta, M., Mazumder, U. K., Pal, D. K., \& Bhattacharya, S. (2003). Anti-steroidogenic activity of methanolic extract of Cuscuta reflexa Roxb. stem and Corchorus olitorius Linn. seed in mouse ovary. Indian Journal of Experimental Biology, 41, 641-644.

Güllüce, M., Adıgüzel, A., Oğütçü, H., Şengül, M., Karaman, I., \& Şahin, F. (2004). Antimicrobial effects of Quercus L. extract. Phytotherapy Research, 18, 208-211.

Hacıoğlu, Ö. (2005). Essential oil compositions and antimicrobial activity properties of seven species belonging to Achillea (anthemideae) genus filipendulinae and santolinoidea sections (Master Thesis). Balıkesir University, p.67, Balıkesir, Turkey.

Kırbağ, S., Erecevit, P., Zengin, F., \& Güvenç, A. N. (2013). Antimicrobial activities of some Euphorbia species. African Journal of Traditional Complementary and Alternative Medicine, 10, 305-309.

Koca, U., Kueli-Akkol, E., \& Sekeroğlu, N. (2011). Evaluation of in vivo and in vitro biological activities of different extracts from cuscuta arvensis beyr. (Convolvulaceae). Natural Product Communications, 6,1433-1436.

Koca-Caliskan, U., Aka, C., \& Yalçın, F. (19-22 May, 2014). Preliminary Phytochemical Analysis Radical Scavenging Activity of the Cuscuta arvensis extracts. Book of abstracts - VIII CMAPSEEC Durrës, Albania, p.117.

Koca-Caliskan, U., Yilmaz, I., Cetin, A., \& Sekeroglu, N. (2014). Assesment of the pharmacological activitiy of ikşut. Book of abstracts VIII CMAPSEEC Durrës, Albania, 19-22 May, , p.108.

Koca-Caliskan, U., Yilmaz, I., Cetin, A., Taslıdere, A., Yalçın, F., Aka, C., \& Sekeroğlu, N. (2018). Cuscuta arvensis beyr "dodder": in vivo hepatoprotective effects against acetaminopheninduced hepatotoxicity in rats. Journal of Medicinal Food. 21, 625-631.

Kuta, F. A. (2008). Antifungal effect of Calotropis procera stem bark on Epidermophyton flocosum and Trichophyton gypseum. African Journal of Biotechnology, 7, 2116-2118.

Küçükgül Güleç, A., Erecevit, P., Yüce, E., Arslan, A., Bağc1, E., \& Kırbağ, S. (2014). Antimicrobial activity of the methanol extracts and essential oil with the composition of endemic Origanum acutidens (Lamiaceae). Journal of Essential Oil Bearing Plants, 17, 353-358.

Lee, M. S, Chen, C. J., Wan, L., Koizumi, A., Chang, W. T, Yang, M. J., Lin, W. H., Tsai, F. J., \& Lin, M. K. (2011). Quercetin is increased in heat-processed Cuscuta campestris seeds, which 
enhances the seed's antiinflammatory and anti-proliferative activities antiinflammatory and anti-proliferative activities. Process Biochemistry, 46, 2248-2254.

Liu, J. H., Jiang, B., Bao, Y. M., \& An, L. J. (2003). Effect of Cuscuta chinensis glycoside on the neuronal differentiation of rat pheochromocytoma PC12 cells. International Journal of Devalopmental Neuroscience, 21, 277-281.

Mateen, A., Suresh, P. V. K. \& Parwez, A. (2011). Evaluation of antibacterial activity of Cuscuta reflexa and abutilon indicum. International Journal of Pharma and Bio Sciences, 2(4), 355361.

Nisa, M., Akbar, S., Tarıq, M., \& Hussain, Z. (1986). Effect of Cuscuta chinensis water extract on 7 , 12- dimethyl benz[a]anthracene-induced skin papillomas and carcinomas in mice. Journal of Ethnopharmacology, 18, 21-31.

Noureen, S., Noreen, S., S. A., Ghumman, Batool, F., \& Bukhari, S. N. A. (2019). The genus cuscuta (convolvolacea): an updated review on indigenous uses, phytochemistry, and pharmacology. Iranian Journal of Basic Medical Sciences, 22, 1225-1252.

Oh, H., Kang, D. G., Lee, S., \& Lee, H. S. (2002). Angiotensin converting enzyme inhibitors from Cuscuta japonica Choisy. Journal of Ethnopharmacology, 83, 105-108.

Okiei, W., Ogunlesi, M. \& Ademoye, M. A.(2009). An assessment of the antimicrobial properties of extracts of various polarities from chasmanthera dependens, emilia coccinea and cuscuta australis, herbal medications for eye diseases. Journal of Applied Sciences, 9, 4076-4080.

Pal, D. K., Mandal, M., Senthilkumar, G. P., \& Padhiari, A. (2006). Antibacterial activity of Cuscuta reflexa stem and Corchorus olitorius seed. Fitoterpia, 77, 589-591.

Palombo, E. A. (2009). Traditional medicinal plant extracts and natural products with activity against oral bacteria: potential application in the prevention and treatment of oral diseases. Evid-Based Complementary and Alternative Medicine, 2011, 1-15.

Shayanfar, S. (2015). Study of antibacterial activities of Cuscuta campestris Yuncker. on Alhagi persarum L. base by bioautography method. Kerman University of Medical Sciences Faculty of Pharmacy. Doctor Thesis.

Sin, B., Kadioglu, I., \& Onaran, A. (2017). Antifungal activity of parasitic plant (Orobanche ramosa L. Cuscuta campestris Yunck. and Viscum album L.) extracts against some plant pathogenic fungi. Turkish Journal of Weed Science, 20, 61-69.

Singh, D. \& Shailajan, S. (2016). Simultaneous quantification of pharmacologically active markers quercetin, kaempferol, bergenin and gallic acid from cuscuta campestris yuncker using HPTLC. Pharmaceutica Analytica Acta, 7, 2153-2435.

Stanilova, S. A., Zhelev, Z. D., \& Dobreva, Z. G. (2000). Preliminary studies on the immunomodulatory effect of the $\mathrm{C} 3$ binding glycoprotein isolated from Cuscuta europea. International Journal of Immunopharmacolology, 22, 15-24.

Summit, C., Jatin, T., Pradeep, K., \& Yogesh, P. (2010). Comparative evaluation of antimicrobial potential of different extracts of Cuscuta reflexa growing on Acacia arabica and Zizyphus jujuba. Pharmacognosy Journal, 9, 293-296.

Şekeroğlu, N., Koca, U., \& Meraler S. A. (2012). (Geleneksel bir halk ilacı: ikşut). a traditional folk medicine: ikşut. Yuzuncu Yul University Journal of Agriculture Science, 22, 56-61.

Şen, A., Aydemir, T., Tüysüz, M., S Birteksöz, Tan, S., Doğan, A., \& Bitiş, L. (9-13 may, 2018) Antioxidant and antimicrobial activities of different extracts from Cuscuta sp. growing wild in province of Mardin. 2nd International Scientific Research Congress (2. Uluslar Aras1 Bilimsel Araştırmalar kongresi) UBAK. Mardin- Turkey, p.227.

Okut, N., Yıldırım, B., Ekici, K., Terzioğlu, Ö., \& Özgökçe, F. (2018). Identification of Chemical 1Composition and Antibacterial Properties Juniperus oxycedrus L. subsp. oxycedrus Leaf Essential Oil. Yuzuncu Yll University Journal of Agriculture Science, 28(2), 186-191.

Umehara, K., Nemoto, K, Ohkubo, T., Miyase, T., Degawa, M., \& Noguchi, H. (2004). Isolation of a new 15- membered macrocyclic glycolipid lactone, Cuscutic Resinoside a from the seeds of Cuscuta chinensis: a stimulator of breast cancer cell proliferation. Planta Med., 70, 299-304.

Yen, F. L., Wu, T. H., Lin, L.T., \& Lin, C.C. (2007). Hepatoprotective and antioxidant effects of Cuscuta chinensis against acetaminophen-induced hepatotoxicity in rats. Journal of Ethnopharmacology, 111, 123-128. 
Yen, F. L., Wu, T. H., Lin, L.T., Cham, T. M., \& Lin, C. C. (2008). Concordance between antioxidant activities and flavonol contents in different extracts and fractions of Cuscuta chinensis. Food Chemistry, 108, 455-462. 